Original Research Paper

\title{
The Place of Transport Infrastructures among the Economic Factors of Foreign Direct Investment Attractiveness in the Meda-10 Region
}

\author{
Samir Saidi and Sami Hammami \\ Department of Economics, Faculty of Economics and Management, Sfax, Tunisia
}

Article history

Received: 19-03-2015

Revised: 01-03-2016

Accepted: 02-03-2016

Corresponding Author:

Samir Saidi

Department of Economics,

Faculty of Economics and

Management, Street of Airport,

Km 4.5, LP 1008, Sfax, Tunisia

Email:samirsaidi05@yahoo.com

\begin{abstract}
This article aims to evaluate the contribution of transport infrastructures to improve the attractiveness of the Foreign Direct Investment (FDI) in the countries of the MEDA-10 region. The present article is formed by two sections. In the first one, we have a theoretical study of the FDI attractiveness and an explanation of the transport role among the territorial attractiveness factors. In the second section, we represent the empirical study. The obtained results, by using an econometric model with panel data, showed that the traditional determinants of FDI (GDP, economic openness level, inflation, exchange rate ...) have the most significant influence on the international investors' decision. Also, transportation has a significant influence and it is considered as a new important factor of FDI attractiveness with strategic issues that cannot be avoided.
\end{abstract}

Keywords: Territorial Attractiveness, Foreign Direct Investment, Transport Infrastructures, Economic Factors

\section{Introduction}

In Developing Countries (DCs), the awareness of the positive effects of Foreign Direct Investment (FDI) is established from the $70 \mathrm{~s}$. These countries have become more open to international trade and commercial flows by giving more importance to FDI (Ozyurt, 2008). Cheriet and Tozanli (2007) show that the literature treats this type of investment in three principal points; the FDI determinants, their effects and impacts on host economies and entry modes of Multinational Corporations (MNCs) and implementation strategies in the host countries.

For host economies, MNCs represent a major creator of jobs with higher salaries than those given by domestic firms. Also, they support the construction of a competitive local industry by enhancing the effects of demonstration, imitation and contagion and by the stimulation of competition between firms. For local ones, acquisition of advanced technologies is easier in an environment where the MNCs exist. Also, foreign companies help to increase the currency reserves by improving exports. For these reasons, host countries believe that they must develop a strong attractiveness based mainly on a set of traditional determinants (economic and political stability, natural resources, cost and qualification of manpower and tax measures proposed to motivating foreign investors and a high openness degree to the regional and international environment ...).

In recent years, MNCs consider transport as a new FDI determinant with a growing importance. For this reason, the host countries become increasingly interested to improve the transport quality. The latter one was watched, for a long time, as the first source of negative externalities, today it becomes a major determinant of territorial attractiveness especially in developing countries. This change, essentially caused by the increased internationalization of firms, increased their need for a transport system with high added value, highperformance, based on a modern and developed infrastructure capable to respond effectively to their needs. Some studies speak about the influence of transport infrastructure on the firms work. Erenberg (1993) sees that, if the State does not provide these types of infrastructure, the national private sector and multinational companies operate less efficiently. Actually, in a context of strong international competition, firms give more importance to the time factor. Indeed, a delivery just in time, stocks at zero level, goods more sensitive to climatic conditions are all factors which make transportation a production element as well as capital and labor. 
The economic importance of transport infrastructure is largely discussed in an extensive literature (Asiedu, 2002; Sekkat and Veganzones-Varoudakis, 2004). However, the role of these infrastructures in the FDI attractiveness is lightly treated by economists. Few studies support the idea that justifying the high MNCs attraction to areas where transport systems are more efficient (Coughlin et al., 1991; Loree and Guisinger, 1995).

This article analyzes the role played by transport as a FDI determinant. In an econometric model using panel data over the period 1990-2013, we introduce the transport with other economic factors to demonstrate its importance in FDI attractiveness for the MEDA-10 countries. To this end, we present at the beginning a definition of territorial attractiveness. Then, we study transport and its role as a determinant of FDI in the countries of our sample. Finally, we present our model, results, interpretations and retained conclusions.

\section{The Theoretical Basis of the Foreign Direct Investment Attractiveness}

To define territorial attractiveness Coeure and Rabaud (2003) say "the ability of a territory to attract and retain businesses". Indeed, the attractiveness of a territory is the ability to attract and retain business, companies and people based on their merits. Power exercised more or less hard on firms and households can facilitate their integration into the local economy and contribute to its development.

According to Thiard (2005), territorial attractiveness is a set of attributes of the territory able to convince a Multinational Company (MNC) to choose it as a new relocation site for one or more of its establishments. These attributes are more or less given and inherited as appropriate. In the same vein, Hatem (2004) gives a distinction between two kinds of attractiveness. A first one known simple attractiveness defined as "the ability of a territory to provide for actors the conditions which convince them to locate their projects in their territory rather than another." The second one is a complex attractiveness produced by political decisions and various measures implemented by the developers of a territory to strengthen the simple attractiveness and to make the territory in question more favorable for business location.

In the same context, Mouriaux (2004) presents the attractiveness of a territory as its ability to attract and retain activities with high content of skilled labor. Finally, according to Lamarche (2003), a country is attractive when it has the aptitude to attract foreign investors. In this sense, the volume of FDI present in a territory is a good indicator of its attractiveness. Borja (2007) says «When we speak about attractiveness, we often thought to the capture of foreign capital and investors".
During 2006, to improve their attractiveness 93 countries brought 184 modifications to their national regulatory measures among which 147 are more favorable to the FDI (UNCTAD, 2006). The choice of openness and integration into the global economy especially from the developing countries generate a multiplication of the multinational company number as well as the number of their affiliates. Today there are about $82000 \mathrm{MNCs}$ in the world, counting 810000 foreign affiliates. In 2008, these last ones are the source of a third of total world exports of goods and services. So they offer more than 77 million jobs over the entire world (UNCTAD, 2006).

To compare the territorial attractiveness, a wide literature proposes diverse elements (institutional, economic, industrial and commercial). Cumenge (2009) classifies these criteria; firstly he presents an institutional and macroeconomic environment containing a set of necessary criteria for any investment. Then, there is an economic and social environment formed by structural criteria and finally incentive criteria in terms of public policies (the fiscal measures, the privatization programs). Other authors including Bouinot (2010); Hidane et al. (2002) say that the basic infrastructure and exactly that of transport is a major determinant of the territorial attractiveness.

Several authors study the economic role of transport in order to demonstrate its importance either for the firm in a microeconomic framework or for the entire economic activity in a wider macroeconomic framework. As has been a FDI determinant which has a very important role in the internationalization of firms, the transport can strengthen the attractiveness of territories and increase their competitiveness.

\section{Transportation: Factor of Foreign Direct Investment Attractiveness}

In their book, Didier and Prud'homme (2007) explain the transport service as an intermediate consumption, rarely asked in and of itself. It is an auxiliary of professional, leisure or production activity. Transport demand can be understood only in relation to lifestyle and production activity, including its technical structure and space. But transportation is not a just passive translation of travel needs. It has its own dynamic that will make it an essential instrument for space structuring. Thus, transport performs other functions in the global economy. It is a key factor of globalization allowing companies and individuals to take better advantages of this phenomenon. Indeed, companies and individuals can all the more benefit from globalization that transportation systems are efficient and effective.

More specifically, into the economic activities relocation and the firms' Internationalization, the quality 
and capacity of the physical infrastructure (airports, roads, public transport, etc....) in a host country are inherent factors in the decision-making process of location of multinational corporations. To explain more the role of transport, Brainard (1997) finds that the transportation costs, the customs duties and the economies of scale in the firm help the American companies to increase their investments abroad.

Also in a host country, the appropriate management of transport systems is a necessary condition to improve the firms' competitiveness. In a localization project of activities abroad, the company demands the best possible transportation service providing the least expensive connectivity between the various subsidiaries. For MNCs, a good management of the transport systems is indispensable element in a world where the time constraints and flexibility must be managed effectively.

However, the impact of the transport costs on the choices of the subsidiaries new locations varies from one activity to another. In the industrial field, the factory location depends directly on these costs if their part increases significantly the production cost. Minimizing transportation cost remains always a major objective; it is one of the location determinants which are necessary to analyze. In addition, most firms believe that the transport logistics helps to minimize expenses. Today they have an increasing requirement concerning infrastructure and conditions of transport in which they will organize the movement of goods and staff. Each firm wishes a good satisfaction of its transportation needs to maintain its proper functioning, which postulates frequently the choice between several modes of transport.

Currently, the modern economy is dependent to labor quality and flexible production strategies. In the context of globalization and market integration, strengthening the firm's competitiveness requires efficient, competitive and connected transport systems. Indeed, an industrial company chooses its production site based primarily on the access degree to markets, inputs and quality of transportation services that will be needed. According to (Dupuch and Milan, 2002) "the location of a factory near the national network facilitates the production processes "juste in time" and completes the accessibility attraction".

Several countries know the importance of transportation to the FDI attractiveness. They have an interest to improve the quality and capacity of their transport infrastructure to enhance their competitiveness and increase their attractive effect exerted on the MNCs. For example, in the North Africa, European investment, intended to develop subcontracting relationships, is the most promising in terms of employment and technology transfer, but the development of these activities is intimately related to infrastructure and logistics platform building (FEMISE, 2009). In addition, several firms internationalize their added value chains and they locate operations abroad, consequently their needs of movement between different subsidiaries become greater. So a good transport logistics is essential to ensure the best connectivity between clients and suppliers and to improve their efficiency and productivity and thus the overall competitiveness of the firm.

In the new economy where MNCs production networks are integrated on a global scale and consumers become more and more pressed and demanding, time becomes a real source of competitive advantage. Rapid access to a logistics platform, or in other words the quality of land transport infrastructure that connect the various intra-regional poles of growth, appears as an important location factor. In this context, the most important contribution of transports is that they are an essential element of connectivity and a major asset of FDI attraction strategy.

In Asia, land transportation has benefited from a big project to upgrade. In the Asian context (ESCAP, 2009) indicate that in order to help domestic enterprises to adapt well to the globalization phenomenon has approved in 1992 a project for the development of land transport infrastructure. This step aims to facilitate import and export transactions and improving the regional integration providing to local firms more resources to penetrate global markets.

Also, the project examines the potential of intermodal installations such as dry ports and inland container parks. According to (ESCAP, 2009), "dry ports, strategically located where different transport networks converge, allows an efficient transfer of goods from one mode to another, including those transported in standard containers, which ensures optimum utilization of the networks as a whole. These dry ports have similar functions to those seaports."

These installations represent important elements for building a successful intermodal transport system. They help to create a favorable environment for foreign direct investment and therefore for MNCs. Subsequently, these firms act as an accelerator of international trade which generates a wider development of industrial clusters around providing a significant level of economic activity.

In the Maghreb, maritime transport is the backbone of its commercial exchange with the European Union. Upgrading the port systems of the North Africa countries to international standards is a carrier of productivity gain for supply chains and competitiveness of local economies. However, even these projects increase the port capacity and facilitate trade between the two Mediterranean shores, the problem of logistics infrastructure in the country MATE does not stop there, we also turn to the situation of land infrastructure. Indeed, in this region roads remain insufficient and rail freight is weak and unable to provide a good access to the port areas (Invest in Med, 2009). 
This situation is being changed with large political works to give more importance to logistics functions. The highway modernization, the projects connecting ports with rail networks and the creation of connected transport systems help MNCs to manage better the extended supply chains. But MNCs increasing number in the world generates larger and more complex supply chains. The efficient management of these chains requires developed logistics zones in the country home offering to MNCs the optimal exploitation of their resources.

Indeed, creating a logistics area needs a grouping of a large number of big warehouses on the same zone (Bernadet, 2008). This type of storage helps MNCs to reduce the warehousing costs and deliver commands with faster and more reliable ways. Concerning transport, costs decrease if the transported quantities increase, where from the shift towards larger tonnages modes such as rail. Another factor that must be carefully studied to build logistics zones is its location, which must meet some conditions and satisfy several constraints simultaneously. Indeed, it is necessary to ensure accessibility and connectivity of the area with the road and motorway networks and a direct connection with the railways.

Unctad (2006) shows that the FDI attracted by Developing Countries (DCs) increase rapidly passing from $27.41 \%$ in 1998 to $36.48 \%$ in 2005 . These verify that DCs become an important partner in the globalization phenomenon and international trade. MNCs give more importance to the relocation of subsidiaries in these countries. In our empirical section, it is necessary to determine the various factors of FDI attractiveness in host countries. Our sample is formed by ten developing Mediterranean countries working more than others to attract FDI. The goal is to determine the most important factors of FDI attractiveness in this area and demonstrate the role of transport among them.

\section{The Analytical Framework}

The purpose of this chapter is to verify the following hypothesis:

HYPOTHESIS: Transport infrastructure affects FDI attractiveness in the host country and determines the MNCs competitiveness.

To evaluate the impact of transport infrastructure on the territorial attractiveness, we proceed to test the following hypothesis derived from the central assumption of our analysis.

H1: Population size and GDP level are the major FDI determinants in host countries.

The role of economic factors in FDI attractiveness is widely studied in several works. Among the strongest determinants of the FDI attractiveness are the local market size, its dynamism and growth that reflect the level of economic growth in a country. Also, the GDP level in the host country directly influences the decision of the company with foreign capital. If this level is high a greater purchasing power in these countries will be helping the company to achieve economies of scale. In addition, the large size of the population in the host country indicates the availability of cheaper labor force with good qualification in some countries:

H2: Transport infrastructure increases the FDI territorial attractiveness.

In their studies, several authors including (Loree and Guisinger, 1995; Asiedu, 2002; Morisset, 2000)) assume the transport infrastructure is essential to improve the qualities of territories. They have a growing positive impact on the host country's attractiveness. In the host country, Multinational Corporations (MNCs) and domestic firms functioning is largely dependent on the capacity and quality of existing transport infrastructure and especially those that provide international transport. In addition, Zhou et al. (2002) explain that the transport infrastructure is directly related to the nature of the production which requires the availability of roads, railways, ports and other installations for operational efficiency. Also, with the increased competition, companies are seeking to distinguish themselves by some of their offerings. They choose to locate beside ports and well equipped logistics zones to ship their products in the best conditions:

\section{H3: Transports promote vertical FDI}

The vertical location strategy supposes, on the one hand, the low cost of international transports and the high performance of these systems in the host countries. On the other hand, almost all production is transported to the original country or to other MNCs subsidiaries in different sites. In this sense, the role of transport becomes more critical and directly involved in the determination of these subsidiary location sites:

H4: FDI attractiveness is directly influenced by
economic factors

Several researchers discuss the importance of institutional factors in the FDI attractiveness in the developing countries. But at the same time, the effect of economic factors is well treated by the same authors. They insisted on the effect of inflation rates, economic openness, change rates, interest rates, natural resources and many others. They see that in some cases, despite the poor grades on the institutional bases, several countries capture well respected volumes of FDI due to their advantages over the economic scale. 


\section{Description of Research Methodology}

Using econometric models to analyze the region's attractiveness and compare their competitiveness is a widely used tool in the economic literature. They serve to explain the attraction or repulsion dynamics of trade flows between the different parts of the world. To study the multinational firm choices in their research for a new implantation site, Faouzi, (2004); Dupuch and Milan (2002) apply such econometric models.

In our study, we consider the transformed CobbDouglas production function. The basic considered model in our empirical validation test is taken from the literature on the economic determinants of FDI in the host countries. Our model is presented in its following original form:

$$
y_{i, t}=\alpha+\sum_{k=1}^{k=K} \beta_{K} X_{i t}^{K}+\varepsilon_{i, t}
$$

With:

$y=$ Endogenous variable

$\alpha=$ constant term

$X_{i t}=$ Group of explanatory variables

$\varepsilon_{i, t}=$ Residual error term

The construction of the econometric model requires some qualitative and quantitative variables with different coefficients. In assessing the validity degree of these coefficients, a Student's test (in the case of estimation by the ordinary least squares method) or Wald (in the case of an estimation of a random effects model) must be performed.

\section{Description of Variables}

\section{The Dependent Variable}

$\mathrm{FDI}_{\mathrm{it}}$ : It is the dependent variable that refers to the foreign direct investment entry flows (in thousands of current dollars) in the host countries of our study (MEDA-10). They represent the developing Mediterranean countries most interested to the FDI attractiveness mainly of European origin. They are also countries that receive large volumes of FDI poured into the region. We try to explain this endogenous variable using a set of explanatory variables.

\section{The Exogenous Variables}

POP: Refers to the population size of a host country $i$ at time $t$ (in million persons). This variable is an indicator in terms of market size. Generally the most populated countries are more attractive than the ones with low populations. We expect a positive effect of this variable.

GDP: Gross domestic product gives a clear idea about the purchasing power in the country. Higher GDP describes a market that attracts more FDI. In the literature, this variable was very relevant in horizontal implementation strategies and a little less in the vertical ones. We test if the FDI directly dependent on this variable.

OPEN: Openness rate represents the country openness degree; attracting FDI is also dependent on the integration degree into the global economy. The economy's openness is measured by the volume of trade as a percentage of GDP, in other words the ratio trade (exports + imports) to GDP.

INF: High inflation rate discourages FDI. Generally, international investors prefer countries with lower rates. So, if a country has a relatively high inflation rate FDI will decrease automatically, it is the negative effect of this variable.

TRSP: In a large part of the empirical studies, the transport infrastructure is generally represented by the total number of paved roads. In our present work, we took the kilometer number of highways in each country of our sample as a proxy for transport infrastructure.

CHAN: The exchange rate of the national currency to U.S. dollars measures the external competitiveness of selected countries in the sample. Its effect is ambiguous. Under normal conditions, the domestic currency appreciation makes FDI inflows less interesting, depreciation is rather attractive.

To estimate model, the used data cover the period going from 1990 to 2012 and relate to Algeria, Cyprus, Egypt, Israel, Jordan, Malta, Morocco, Syria, Tunisia and Turkey: The Mediterranean developing countries, so we have 230 observations in total. The data result from the data bank of the World Bank. In the following Table 1 , we present the variables used in the empirical framework and the sign of the expected effect on the variability of the endogenous part.

\section{Descriptive Statistics and Correlation between Variables}

\section{Descriptive Statistics}

To obtain a clear idea about the nature and characteristics of the used explanatory variables, we must treat the descriptive statistics. It is an essential element that can give us a sense, an expression for the required informations.

Table 2 shows considerable differences between the observed standard deviations. For the rest of the study, all variables will be subjected to a logarithmic transformation to reduce the impact of these differences.

Table 1. Explanatory variables

\begin{tabular}{lll}
\hline Variables & Meaning & Signe \\
\hline Pop & Population & + \\
GDP & Gross domestic product & + \\
ONP & Openness rate & + \\
INF & Inflation rate & - \\
TRSP & Transport infrastructures & + \\
CHAN & Change rate & $+/-$ \\
\hline
\end{tabular}


Table 2. Descriptive statistics

\begin{tabular}{|c|c|c|c|c|c|c|c|}
\hline & FDI & POP & GDP & OPEN & INF & TRSP & CHAN \\
\hline Mean & 2716.978 & 35915.55 & 141713.8 & 69.63158 & 28.44737 & 19.97368 & 13130.03 \\
\hline Median & 767.5895 & 10276.00 & 107714.0 & 70.50000 & 8.500000 & 21.00000 & 12129.00 \\
\hline Maximum & 22046.00 & 73914.00 & 376869.8 & 126.0000 & 106.0000 & 32.00000 & 25763.00 \\
\hline Minimum & 76.28000 & 5809.000 & 12236.80 & 30.00000 & 2.000000 & 11.00000 & 2482.000 \\
\hline Std. Dev. & 5394.884 & 28465.30 & 129807.3 & 27.08768 & 32.55902 & 5.957133 & 10069.21 \\
\hline Jarque-Bera & 1097.244 & 59.32035 & 41.43619 & 32.28627 & 60.64972 & 20.13912 & 60.61224 \\
\hline Observations & 380 & 380 & 380 & 380 & 380 & 380 & 380 \\
\hline Cross sections & 10 & 10 & 10 & 10 & 10 & 10 & 10 \\
\hline
\end{tabular}

Table 3 . Correlation of variables

\begin{tabular}{|c|c|c|c|c|c|c|c|}
\hline & FDI & POP & GDP & OPEN & INF & TRSP & CHAN \\
\hline$\overline{\mathrm{IDE}}$ & 1.000000 & 0.060665 & 0.197846 & 0.238407 & -0.183087 & 0.025434 & 0.423097 \\
\hline POP & 0.060665 & 1.000000 & 0.151208 & -0.239962 & 0.399022 & -0.398521 & 0.151391 \\
\hline PIB & 0.197846 & 0.151208 & 1.000000 & -0.246971 & 0.328501 & -0.369731 & 0.272329 \\
\hline OUV & 0.238407 & -0.239962 & -0.246971 & 1.000000 & -0.360422 & 0.286179 & -0.120931 \\
\hline INF & -0.183087 & 0.399022 & 0.328501 & -0.360422 & 1.000000 & -0.013839 & 0.493252 \\
\hline TRSP & 0.025434 & -0.398521 & -0.369731 & 0.286179 & -0.013839 & 1.000000 & -0.281959 \\
\hline $\mathrm{CHG}$ & 0.423097 & 0.151391 & 0.272329 & -0.120931 & 0.493252 & -0.281959 & 1.000000 \\
\hline
\end{tabular}

In addition, the FDI has a significant difference between the minimum and maximum values. So, we can say that the volume of inward FDI in each country varies significantly and subsequently the territorial attractiveness depends on a number of factors. Concerning the distribution of variables, the Jarque-Bera statistic shows its normality.

\section{Correlation between Variables}

A rapid analysis of Table 3 shows clearly that all the correlation levels between variables are low. So, we can say that in our model the variables do not have autocorrelations that may risk the work. So we can continue our estimation by applying the unit root and cointegration tests.

\section{Study of Stationarity and Cointegration Relationship}

To study the series stationarity, unit root tests are the most commonly used in empirical research. However, these test applications in an econometric study using panel data are somewhat recent. Levin and Lin (LL); Im, Pesaran and Shin (IPS) provide the most used tests. In this section, we try to study the properties of non-stationarity, we use Levin Lin and Im, Pesaran and Shin tests:

$$
\Delta y_{i, t}=\alpha_{i}+\theta_{i t} \beta y_{i t-1}+\sum_{i=1}^{p} \gamma_{j} \Delta y_{i t-j}+e_{i t}
$$

In this test, we used

$\mathrm{e}_{\mathrm{it}}$ : The random term for $\mathrm{t}=1,2, \ldots, 23$,

$\mathrm{p}$ : The number of lags which allows us to eliminate the autocorrelation of residuals and minimize Akaike information criterion.

To verify the group stationarity, we used the IPS method. This test gives us a more robust result, also it helps us to overcome the low power of LL tests in small samples. The IPS method provides a unit root test in the context of a panel data model using the individual statistics mean of the regressions. Alternative statistic $\bar{t}$ allowing testing the null hypothesis of unit root for all $\mathrm{i}(\beta \mathrm{i}=0)$ must be exactly respected by the used data:

$$
\bar{t}_{N T}\left(p_{i}\right)=\frac{1}{N}=\sum_{i=1}^{N} t_{i T}\left(p_{i}\right)
$$

$t_{i t}=$ Represents the estimated ADF tests with pi lagged differences

$N=$ The number of groups $\mathrm{N}=10$

$T=$ Series length $\mathrm{T}=23$

The observation total number equal to 230 .

Im, Pesaran and Shin propose the use of the standardized following statistics:

$$
Z_{i}=\frac{\sqrt{N}\left(\bar{t}_{N T}-E\left(\left(\bar{t}_{N T}\right)\right)\right.}{\sqrt{\operatorname{var}\left(\bar{t}_{N T}\right)}}
$$

$E\left(\bar{t}_{N T}\right)=$ The arithmetic mean of individual ADF statistics $\operatorname{var}\left(\bar{t}_{N T}\right)=$ The variances of the individual ADF statistics

Given that $\beta i=0$, the IPS test shows that the standardized statistics converges weakly to the reduced centered normal distribution, which allows to compare it to the critical values of the distribution $N(0,1)$.

The IPS test shows that the set of data series is stationary in level, but in first difference it is affected by a unit root (Table 4). It should be noted that the number of maximum lags is fixed to 3; the lag numbers selection for each individual is programmed for this test by Pedroni. 
Table 4. Unit root test

\begin{tabular}{lllll}
\hline & In level & & In first difference & \\
& - & & -1 \\
& Calculated-t & Prob & Calculated-t & Prob \\
\hline FDI & -2.6292 & 0.1056 & -2.5991 & 0.0113 \\
POP & -3.7308 & 0.0523 & -6.2005 & 0.0001 \\
GDP & -2.8108 & 0.0755 & -5.8184 & 0.0002 \\
OPEN & -4.1766 & 0.0649 & -6.5374 & 0.0000 \\
INF & -0.9843 & 0.7368 & -4.2388 & 0.0046 \\
TRSP & -2.8174 & 0.0746 & -6.1267 & 0.0001 \\
CHG & -4.0660 & 0.0561 & -6.8641 & 0.0000 \\
\hline
\end{tabular}

Table 5. Pedroni cointegration test

\begin{tabular}{llllllll}
\hline & V-stat* & Rho-stat* & Pp-stat* & Adf-stat* & Rho-stat** & Pp-stat** & Adf-stat** \\
\hline FDI, POP, GDP, OPEN, INF, TRSP, CHAN & -1.8660 & -2.9515 & -1.9650 & -5.3886 & -4.3390 & -1.9430 & -5.5012 \\
\hline$* *$ Tests based on BETWEEN dimensions & & & & & & &
\end{tabular}

* Tests based on WITHIN dimensions

Applying the IPS test, we find that the property of non-stationarity for all variables in the panel is confirmed that brings us to study the existence of a longterm relationship between these variables. The most appropriate test to examine the existence of cointegration relationship is the Pedroni test based on unit root tests on the estimated residuals (Table 5). The idea of cointegration tests on panel data comes from a test of the unit root presence in the estimated residuals.

Pedroni has developed seven cointegration tests on data from homogeneous and heterogeneous panel; these tests take into account the heterogeneity in the cointegrating relationship. These Pedroni tests are divided into two groups, a first consisting of four tests based on the dimension "Within" and a second one component three tests based on dimension "Between". These two categories are based on the null hypothesis of no cointegration, the distinction between the two groups is at the alternative hypothesis:

$$
H_{1}\left\{\begin{array}{l}
\rho i=p<1 \forall i: \text { within } \\
\rho i<1 \forall i: \text { between }
\end{array}\right.
$$

Pedroni has shown that under appropriate normalization based on Brownian motion functions, each of the 7 statistics follows a normal distribution centered reduced for $\mathrm{N}$ and $\mathrm{T}$ important enough.

From the results of Pedroni cointegration tests, we can notice that all the statistics are below the critical value of the normal distribution for a threshold of 5\% (1.64). Therefore, all of these tests require the existence of a cointegration relationship.

\section{Econometric Specification}

By using TSP 4.5 , the test of homogeneity is realized in stages. First, we test the total homogeneity of model, once the null hypothesis of absolute homogeneity is rejected; we have to test the homogeneity of the explanatory variable coefficients and individual constants.

\section{Test of Total Homogeneity}

It is considered $H_{0}^{1}$ the hypothesis of complete homogeneity test and $\mathrm{F}_{1}$ the associated Fisher statistics:

$$
\begin{array}{ll}
H_{0}^{1}: \beta i=\beta \text { et } \alpha i=\alpha & \forall i \in[1, N] \\
H_{a}^{1}: \exists(i, j) \in[1, N] & / \beta_{i} \neq \beta_{j} \text { ou } \alpha_{i} \neq \alpha_{j}
\end{array}
$$

TSP 4.5 gives:

- $\quad \mathrm{F}$ test of $\mathrm{A}, \mathrm{B}=\mathrm{Ai}, \mathrm{Bi}: \mathrm{F}(63,160)=67.386, \mathrm{P}$-value $=[0.0000]$

- Critical $\mathrm{F}$ value for diffuse prior (Leamer, p. 114) $=$ 8.8065

The letter A represents the constant of the model and the letter $\mathrm{B}$ indicates the vector of the explanatory variable coefficients. The realization of $H_{0}^{1}$ Fisher statistics noted $\mathrm{F}_{1}$ followed a Fisher with $(\mathrm{N}-1)(\mathrm{K}+1)$ and NT-N $(\mathrm{K}+1)$ degrees of freedom. In our sample with $\mathrm{K}=6$, the realization value must be compared to the threshold of a Fisher F $(63,160)$. The software gives a $p$ value which is well below the 5\% threshold. According to this result, we reject the null hypothesis of equality of constants and explanatory variable coefficients. Indeed, we cannot speak about a completely homogeneous panel.

\section{Test of Coefficients Homogeneity $\beta i$}

$H_{0}^{2}$ is considered as hypothesis of the coefficients ( $\beta$ ) homogeneity and $F_{2}$ is the related Fisher Statistics:

$$
\begin{array}{ll}
H_{0}^{2}: \beta i=\beta & \forall i \in[1, N] \\
H_{a}^{2}: \exists(i, j) \in[1, N] & / \beta_{i} \neq \beta_{j}
\end{array}
$$


In the context of our sample, the Fisher statistic realization $\mathrm{F}_{2}$, related to $H_{0}^{2}$, is 1.0938 . This value is compared to the Fisher threshold with (N-1)K and NT-N $(\mathrm{K}+1)$ degrees of freedom. The indicated $\mathrm{p}$ value shows that up to $37 \%$, we cannot reject the null hypothesis:

- $\quad$ F test of Ai, B = Ai, Bi: F(54,160) $=1.0938$, P-value $=[0.3694]$

- $\quad$ Critical $\mathrm{F}$ value for diffuse prior (Leamer, p. 114) = 7.5922

According to the obtained result, the panel structure is confirmed and we can assume that there are common factors between the foreign direct investment flows and the explanatory variables for all countries in our sample.

\section{Test of Homogeneity of Constant $\alpha i$}

$H_{0}^{3}$ : Is considered as the null hypothesis of constant homogeneity and F3 is the associated Fisher statistics.

$$
\begin{aligned}
& H_{0}^{3}: \alpha i=\alpha \quad \forall i \in[1, N] \\
& H_{a}^{3}: \exists(i, j) \in[1, N] / \alpha_{i} \neq \alpha_{j}
\end{aligned}
$$

Under the null hypothesis, we impose the equality of constant between different countries. According to the results, the realization of the Fisher statistic denoted $\mathrm{F}_{3}$ associated to the $H_{0}^{3}$ test is 74.7. If this value is compared to the Fisher threshold with N-1 and N (T-1)$\mathrm{K}$ degrees of freedom, in this case $\mathrm{F}(9,216)$, the $\mathrm{p}$ value is well below the threshold of $5 \%$, which gives a null rejected hypothesis:

- $\quad \mathrm{F}$ test of $\mathrm{A}, \mathrm{B}=\mathrm{Ai}, \mathrm{B}: \mathrm{F}(9,216)=74.700, \mathrm{P}$-value $=$ [0.0000]

- $\quad$ Critical $\mathrm{F}$ value for diffuse prior (Leamer, p. 114) $=$ 5.5046

Finally, we have a model of heterogeneous panel, where the coefficients of the explanatory variables are the same for all individuals in the sample and the only source of heterogeneity is the individual constant. Also, these obtained results verify the existence of individual effect in our model written as follow:

$$
\mathrm{y}_{\mathrm{i}, \mathrm{t}}=\alpha_{\mathrm{i}}+\beta^{\prime} \mathrm{x}_{\mathrm{i}, \mathrm{t}}+\lambda_{\mathrm{it}}+\varepsilon_{\mathrm{i}, \mathrm{t}}
$$

With:

$$
\begin{aligned}
\alpha= & \text { Constant } \\
i= & \text { Host country } \\
\lambda_{i t}= & \text { Specific unobservable individual effects to the host } \\
& \text { country } \mathrm{i} \text { at time } \mathrm{t} \\
\varepsilon_{i t}= & \text { The error term }
\end{aligned}
$$

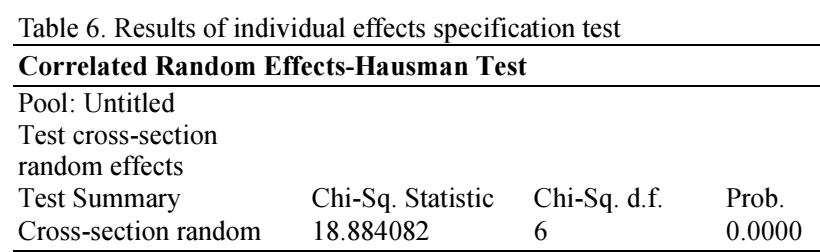

In the next step, we must determine the nature of the individual effects (fixed or random). One of the most used tests, for these individual effects specification, is the Hausman one presented in the Table 6. This test can solve many problems of specification in econometrics. It is mainly used to distinguish the fixed and random effects. The tested hypothesis concerns the correlation between the individual effects and the explanatory variables. Assumptions of Hausman test are:

$$
\begin{aligned}
& H_{0}: E(\alpha i / X i)=0 \\
& H_{1}: E(\alpha i / X i) \neq 0
\end{aligned}
$$

Under the null hypothesis $\mathrm{H}_{0}$, the model can be specified with individual random effects and we must retain the GLS estimator (BLUE estimator).

Under the alternative hypothesis $\mathrm{H}_{1}$, the model must be specified with fixed individual effects and we must retain within estimator (unbiased estimator).

The obtained results are presented in the next Table 6 .

For the considered sample, the statistic realization of the Hausman test is 18.88 . Because the model has six variables $(\mathrm{K}=6)$, this statistic follows a chi-square with 6 degrees of freedom. According to this result, we reject the null hypothesis of no correlation between individual effects and explanatory variables. So, in our model the exogenous variables are correlated with specific structural and timeless volume of FDI received by the host country. Here, we must favor the adoption of a model with fixed effects and retain the unbiased estimator (estimator within).

\section{Results of Regression}

To measure the influence of transport infrastructure and some different economic factors on the territorial attractiveness, we use the following specification:

$$
\begin{aligned}
& \log \left(F D I_{i t}\right)=\alpha+\beta_{1} \log \left(P O P_{i t}\right) \\
& +\beta_{2} \log \left(G D P_{i t}\right)+\beta_{3} \log \left(\text { OPEN }_{i t}\right)+\beta_{4} \log \left(I N F_{i t}\right) \\
& +\beta_{5} \log \left(T R S P_{i t}\right)+\beta_{6} \log \left(C H A N_{i t}\right)+\lambda_{i t}+\varepsilon_{i t}
\end{aligned}
$$

$y_{i, t}=$ Endogenous variable to explain

$\alpha_{i}=$ constant

$x_{i, t}=$ explanatory variables

$\lambda_{i t}=$ Specific unobservable individual effects to the host country $i$ at time $t$

$\varepsilon_{i t}=$ The error term 
Table 7. Regression results of model with fixed effects

\begin{tabular}{|c|c|c|c|c|}
\hline Variables & Coefficient & Std.error & T-statistic & Prob \\
\hline \multicolumn{5}{|c|}{ Dependent variable: FDI } \\
\hline $\mathrm{C}$ & 21.79197 & 5.065014 & 4.302451 & 0 \\
\hline LOG(POP) & 0.096131 & 0.176241 & 0.545454 & 0.5861 \\
\hline LOG(GDP) & 0.36371 & 0.202304 & 1.797833 & $0.0441 * *$ \\
\hline LOG(OPEN) & 3.783502 & 0.973735 & 3.885557 & $0.0001 *$ \\
\hline LOG(INF) & -0.373192 & 0.168229 & -2.218357 & $0.0278 * *$ \\
\hline LOG(TRSP) & 0.504803 & 0.256534 & 1.967782 & $0.0760 * * *$ \\
\hline LOG(CHAN) & 0.640198 & 0.324685 & 1.971749 & $0.0401 * *$ \\
\hline R-squared & 0.605362 & Meandependent var & & 6.410442 \\
\hline S.E. of regression & 1.502102 & S.Ddependent var & & 2.053705 \\
\hline F-statistic & 12.53261 & Sumsquaredresid & & 415.1613 \\
\hline Prob (F-statistic) & 0 & Durbin-Watson stat & & 1.31032 \\
\hline
\end{tabular}

*significant at $1 \%$;

$* *$ significant at $5 \%$;

$* * *$ significant at $10 \%$

The following Table 7 contains the results of the econometric estimation. In this table, we can read the coefficient and the p-value related to each explanatory variable.

To test this model, we adopt the ordinary leastsquares method using the software "eviews 7".

The results estimated by OLS method, in the case where we have a fixed effects model show that, according to the coefficient of determination $\left(\mathrm{R}^{2}=\right.$ $0.6053)$ and the Fisher's test (F-statistic $=12.53)$ it is significant. Also, the obtained statistics show that the Gross Domestic Product (GDP), economic openness (OPEN), inflation rate (INF), transportation infrastructures (TRSP) and exchange rate (CHAN) are significant variables with different thresholds. While the variable related to population (POP) has a not significant influence on the variation in the endogenous variable.

For the first exogenous variable introduced in the model (population), several studies show that it is a major determinant of FDI (Lipsey, 1999; Truman and Emmert, 1999; Love and Lage-Hidalgo, 2000; Obwona, 2001). This variable represents the local market size and then the possibility of a higher domestic demand in these countries. In our case, this variable is not significant and it has a low coefficient. This non-significance is justified by the vertical nature of FDI located in these countries. Also, this result confirms the idea of Basile (2004) that the market size of the host country affects more the horizontal FDI. But, if we are talking about a vertical investment where the large parts of the production are sent abroad as in the countries of our sample, we can find some explanation. According to traditional theory, several studies including those of (Helpman, 1984; 1985; Zhang and Markusen, 1999) show that the differences between the sending countries and the receiving ones of FDI in terms of market size, factor endowments of production technologies and consumer's income encourage the vertical FDI flows.
Also, the GDP level reflects the qualities of the local markets. Usually, a country with a relatively high GDP has a greater purchasing power. Several studies show that the difference in GDP between countries is also a very important determinant of FDI precisely for the vertical type (Gao, 2003; Markusen and Maskus, 1999). The coefficient associated with this variable (GDP level) is significant at 5\%. Also, a high GDP justifies the local market development and the well absorbency capacity of larger production quantities which is sought by the MNC. In the present case, we observe that the GDP level is not very important and the MNC is not very interested to this indicator. So, we can suppose that the $\mathrm{H} 1$ is invalidated if we talk about a vertical FDI. But in the other side, the domestic population size and the GDP level become two factors with a high importance to attract the horizontal FDI in the developing countries.

For these firms, the high economic openness degree (OPEN) is a good indicator of the implementation ease in a foreign country and it represents the procedures simplicity to achieve an export or import operation. In our model, the economic openness degree is significant at the $5 \%$ level. Also, the inflation level appears important and the MNCs are dubious for countries with high inflation levels. They believe that the country is politically and socially unstable; they are cautious and prefer the non implementation in these countries. This explains the negative sense of the significant coefficient at the $1 \%$ level, so any increase in inflation leads to a reduction of inward FDI in a selected country in our study.

Then, we have the variable (Chan), it is the exchange rate of the national currency in U.S. dollars. The instability of the exchange rate is an unfavorable element to the FDI attractiveness. Statistics related to this variable show that the exchange rate is a powerful determinant of FDI to developing countries. In the same order of ideas, Bénassy-Quéré et al. (1999) argue that the exchange rate can be counted among the most important 
economic determinants of FDI and each country should stabilize its currency against the countries may bring to him as much as possible FDI. A depreciation of the local currency may be attractive for foreign investors so that an assessment can lead to repulsion effects.

According to these results, we can say that the $\mathrm{H}_{2}$ is strongly verified and the attractiveness effect of the economic factors is very important in the developing countries.

Also, there are many other variables which variation may increase or decrease the volume of inward FDI in a country. In several works, transportation is considered as a mere geographical distance between an investor and a host country. The authors indicate that the MNCs prefer always the implementation in the near countries which can offer the necessary investment conditions and refuse go to the most distant ones for many manufacturing reasons. In our study, we consider the motorway network (km motorway) as a proxy for transport infrastructure in the host country. A positive sign is expected because the MNCs are usually motivated by the good performance of the transport systems in the host countries (Coughlin et al., 1991; Loree and Guisinger, 1995). In our case, the transport appears as a key determinant of FDI. This result shows that a transport system can improve the quality of FDI territorial attractiveness in the host country in the same way as traditional determinants of FDI.

Indeed, the role of transport is very important for the firm or for any economic activity in the country. We can talk about transportation if we discuss its economic role, environmental externalities, the ability of moving vehicles, the quality of infrastructure, the creation of free trade zones, warehousing and logistics areas in the country. Also, the transport economic role has evolved rapidly in recent years and its importance in business continues to improve.

Finally, these two last results indicate that the transport infrastructure is an important factor which can play a major role to improve the FDI attractiveness power in the developing countries. Also, a high percentage of the vertical FDI in all countries of our sample explains the significance of transport as an explanatory variable in the model. So, according to the obtained result, we can suppose the validity of $\mathrm{H} 2$ and $\mathrm{H} 3$.

\section{Limitations}

In this article, we have tried to bring up the role of transportation as an important factor to attract FDI. In our work, it is presented by the physical infrastructures (number of kilometers of roads) but we can extend the work by introducing the role of transport services and to demonstrate their importance for the functioning of MNCs. Some works say that the competitiveness of private firms depends directly on the quality of transport services provided by the residents of a country to foreign investors.

Also, it would be interesting to test the model with several variables representing the transport infrastructure. For example, the World Bank recently published a Logistics Performance Index, which reflects the quality of transport infrastructure. Other proxies were interesting, as transport costs or indices of "trade facilitation", recently used in the literature. Consequently, limited to road transport variable seems a bit reducer. But in this study, the reduced sample size forces us to choose variables with rather long time series for having applied the usual econometric tests necessary to ensure the robustness of our results.

Concerning the low size of the used sample, we find that, theoretically the countries of the European Union are one of the great sources of FDI directed to developing countries, also the portion of the host countries of the region remains very marginal and they receive only small volumes of FDI. For this reason, we have tried to explain the causes of the low competitiveness of these countries and whether transport may become another factor that can increase the competitiveness of these countries to further attract European FDI.

In order to adequately express the importance of transport in the attractiveness of FDI, we can increase our sample size by introducing new countries and even entire new regions. This is the extension of our field of study which allows for greater results. But the choice of our sample was determined mainly by the low volume of FDI attracted by the Mediterranean developing countries, despite the geographical proximity with a very important source of foreign investment like the European Union.

Finally, one last limit may be found; it is the choice of the explanatory variables. Indeed, in our empirical application, we did not use institutional variables despite their widely verified significance in the economic literature. Practically, we want to value the importance of transportation among the pure economic factors.

\section{Conclusion}

FDI had accompanied the internationalization of companies during the XIX and the early twentieth century. But since the beginning of $70 \mathrm{~s}$, the host countries granted a major importance to the FDI as an efficient catalyst of economic development. This willingness was accentuated in the 90s and 2000. So, the FDI attractiveness was, for a long time, among the most important economic strategies of these countries. They promulgated during the last twenty years a large battery of tax and regulatory measures to encourage MNCs to locate in their territories.

For several years, the FDI attractiveness in the host countries is mainly based on traditional FDI determinants (economic, institutional,). Recently, apart 
from these major factors, movements of FDI in the world depend on a new set of factors. Indeed, the liberalization and the rapid development of international financial markets, the use of transportation more efficient in loading capacity, the quality of service and the fast innovation in the field of ICT has caused a dramatic rise in global FDI flows.

In this study, we studied the FDI attractiveness factors in the region MEDA-10 using panel data in an econometric model with fixed effects. The obtained results confirm ideas shared in several works such as the robustness of economic factors (level of GDP, economic openness, inflation and exchange rates) and the non-significance of the population size in vertical implantation strategies. In addition, our results showed that the transport logistics have a great importance for the MNCs and their location decision abroad is largely affected by the quality of transport systems in the host countries.

Actually, developing countries consider the transport as a new FDI determinant with a growing importance. Recently, the concept of multimodal transport is becoming increasingly relevant and attracts more attention of PVD and FMN at the same time. Such a transport system can have large impacts on economic activities in the host country. In addition to production costs, firms are more interested to the movement cost of goods and information.

\section{Acknowledgement}

The authors would like to thank the anonymous reviewers of this manuscript, as well as a list of other individuals to long to mention here. The authors would also like to acknowledge the editors' efforts in bringing this manuscript to publication.

\section{Funding Information}

No external funding was provided for the present study.

\section{Author's Contributions}

All authors equally contributed in this work.

\section{Ethics}

This article is original and contains unpublished material. The corresponding author confirms that all of the other authors have read and approved the manuscript and no ethical issues involved.

\section{References}

Basile, A., 2004. Contraintes et perspectives de l'investissement étranger direct dans l'espace CEMAC. Rapport CNUCED, Genève, Suisse.
Bénassy-Quéré, A., L. Fontagné and A. Lahrèche-Révil, 1999. Exchange rate strategies in the competition for attracting FDI. CEPII.

Hidane, A., F. Bernoussi and M. Tiurkmani, 2002. Diagnostic de l'attractivité du Maroc pour les investissements directs etrangers.

Faouzi, B., 2004. Risque pays, IDE et crises financières internationales. LEO.

Coeure, B. and I. Rabaud, 2003. Attractivité de la France: Analyse perception et mesure. Laboratoire d'Economie d'Orléans.

Coughlin, C., V.T. Joseph and V. Arromdee, 1991. State characteristics and the location of foreign direct investment within the United States. Rev. Econom. Statist., 73: 675-683. DOI: 10.2307/2109406

Zhou, C., A. Delios and J.Y. Yang, 2002. Locational determinants of Japanese foreign direct investment in China. Asia Pacific J. Manage., 19: 63-86. DOI: $10.1023 / \mathrm{A}: 1014839607180$

Loree, D.W. and S. Guisinger, 1995. Policy and Nonpolicy determinants of U.S. equity foreign direct investment. J. Int. Bus. Stud., 26: 281-299.

DOI: 10.1057 /palgrave.jibs. 8490174

Helpman, E., 1984. A simple theory of international trade with multinational corporations. J. Political Economy, 92: 451-471. DOI: 10.1086/261236

Asiedu, E., 2002. On the determinants of foreign direct investment to developing countries: Is Africa different? World Dev., 30: 107-118. DOI: $10.2139 /$ ssrn. 280062

Helpman, E., 1985. Multinational corporations and trade structure. Rev. Econom. Stud., 5: 443-457. DOI: $10.2307 / 2297663$

ESCAP, 2009. Aménagement et opérationnalisation de ports secs et de corridors de transport intermodal, Forum des ministres asiatiques des transports. Réunion de hauts responsables gouvernementaux.

Mouriaux, F., 2004. Le concept d'attractivité en Union monétaire. Paris EUROPLACE.

Cheriet, F. and S. Tozanli, 2007. Essai de construction d'un score d'attractivité sectorielle des Investissements Directs Etrangers: Cas du secteur agroalimentaire dans le Sud et l'Est de la Méditerranée. Economie rurale.

Hatem, F., 2004. Investissement international etpolitiquesd'attractivité. Economica, Paris.

FEMISE, 2009. Les pays partenaires méditerranéens face a la crise, rapport du FEMISE sur le partenariat euro-méditerranéen.

Cumenge, G., 2009. Les investissements industriels français au Maroc, une étude empirique sur la décennie quatre-vingt-dix. Paris.

Invest in Med, 2009. Investissements prioritaires pour le développement de la logistique en Méditerranée. 
Borja, J., 2007. L'attractivité: Les conditions locales de la réussite globale, l'attractivité des territoires regards croisés. Actes des séminaires, Février, Juillet.

Bouinot, J., 2010. Les facteurs de choix des localisations: Les infrastructures de transport. Cybergeo.

Love, J. and F. Lage-Hidalgo, 2000. Analysing the determinants of US direct investment in Mexico. Applied Economics.

Markusen, J.R. and K.E. Maskus, 1999. Discriminating among alternative theories of the multinational enterprise. National Bureau of Economic Research.

Truman, J. and C. Emmert, 1999. Explaining Japanese foreign direct investment in Latin America, 19791992. Social Sci. Quarterly, 80: 539-541.

Zhang, K.H. and J. Markusen, 1999. Vertical multinationals and host-country characteristics, J. Dev. Econom., 59: 233-252. DOI: $10.1016 / \mathrm{S} 0304-3878(99) 00011-5$

Sekkat, K. and M. Veganzones-Varoudakis, 2004. Trade and foreign exchange liberalization, investment climate and FDI in the MENA countries. Universite' Libre de Bruxelles, Department of Applied Economics.

Brainard, L., 1997. An Empirical assessment of the proximity-concentration trade-off between multinational sales and trade. Am. Econom. Rev., 87: $520-544$.

Obwona, M., 2001. Determinants of FDI and their impact on economic growth in Uganda. Afr. Dev. Rev., 13: 46-81. DOI: $10.1111 / 1467-8268.00030$

Bernadet, M., 2008. Transport et logistique durables: Vers la nécessaire prise en compte de leur interdépendance.
Didier, M. and R. Prud'homme, 2007. Infrastructures de Transport, Mobilité Et Croissance. 1st Edn., La Documentation Française, Paris, ISBN-10: 2110068558, pp: 241.

Morisset, P., 2000. FDI to Africa, policy matters. Mimeo. Thiard, P., 2005. L'offre territoriale: Un nouveauconcept pour le développementdesterritoires et desmétropoles ?.

Lipsey, R., 1999. The location and characteristics of U.S. affiliates in Asia, NBER, Cambridge, Mass.

Dupuch, S. and C. Milan, 2002. Les déterminants des investissements directs étrangers européens dans les pays d'Europe centrale et orientale.

Erenberg, S.J., 1993. The real effects of public investment on private investment. Applied Econom., 23: 831-837. DOI: $10.1080 / 00036849300000137$

Ozyurt, S., 2008. Les investissements directs étrangers entraînent-ils des effets de débordement vers les pays en développement? Etudes et Synthèses, laboratoire montpelliérain d'économie théorique et appliquée.

Lamarche, T., 2003. Territoire: Développement exogène, développement endogène et hétéronomie. Université Pierre Mendes France de Grenoble.

Gao, T., 2003. Multinational activity and country characteristics in OECD countries. Applied Econom. Lett., 10: 255-268. DOI: $10.1080 / 13504850210138496$

UNCTAD, 2006. World Investment Report, 2006: FDI from Developing and Transition Economies: Implications for Development. On Behalf of the United Nations, New Delhi, ISBN-10: 8171886094, pp: 334 . 